\section{Idaho Mountain Wildflowers}

\section{A SCOTT EARLE}

Larkspur Books, PO Box 2720, Sun Valley, Idaho 83353. Telephone: 208-622-4417

224 p, cloth, 2001, ISBN 1-56037-179-X

US\$29.95

Many people appreciate native wildflowers for their beauty, pleasing fragrance, and ecological role, but an increasing number want to be able to identify and to learn more about them. Of those people responding to the 2000-2001 National Survey of Recreation and the Environment, 45\% indicated they participate in viewing wildflowers and natural vegetation. Idaho Mountain Wildflowers introduces native plant enthusiasts to the magnificent wildflowers found in Idaho's spectacular mountains.

Idaho Mountain Wildflowers includes a collection of more than 300 vibrant color images depicting 218 species of native wildflowers. These represent a range of montane, subalpine, and alpine plants. Each plant image is accompanied by a short narration on botanical characteristics, growth habits, habitat, and economic and medicinal uses. Derivations of common and scientific names are discussed along with the history of people for whom plants were named. The historical sketches include many of the early plant explorers in North America such as Bernard McMahon, curator of plant specimens from the Lewis and Clark expedition.

Color images have excellent resolution and reproduction. This, in combination with the relatively large image size, enhances the book's usefulness for observing identifying characteristics and increases the book's aesthetic appeal. The book is 23 X $23 \mathrm{~cm}$ (9 $\mathrm{X} 9$ in) and many pages have only 1 or 2 images with a small area devoted to narration. Observation is further enhanced by some plants being represented by both a close-up photograph of the flowers and by a more distant photograph of the entire plant.

A Scott Earle describes this book as a "photographic compendium of wildflowers" he encountered during years of hiking in the mountains of Central Idaho. It is that and much more. Anyone who views the beautiful wildflower photographs and reads the narration will develop a greater appreciation and understanding of the beauty and diversity of mountain wildflowers. Earle does not claim that this is a guidebook but that it may be used as such. He also states that the book is area specific with all images being taken within $48 \mathrm{~km}$ (30 miles) of the Sun Valley Resort at $1830 \mathrm{~m}(6000 \mathrm{ft})$ elevation or higher. However, most plants included are found in a much larger area. Only 3 plants included in this book are endemic to Idaho. Over one-third are in Hultén's Flora of Alaska and Neighboring Territories (1968) and almost two-thirds are in St John's Flora of Southeastern Washington and Adjacent Idaho (1963).

I would not use Idaho Mountain Wildflowers as a standalone identification guide, but would use it as a supplement to field guides and floras. It is a sample of about $10 \%$ of the over 2000 native vascular plants found in Idaho. There are several good field guides for identifying mountain wildflowers of the Pacific Northwest, Great Basin, and Rocky Mountains but these also only cover a small percentage of the plants in the areas they represent. Many of the plants in Idaho Mountain Wildflowers are not represented in popular field guides. Someone could key out a plant in floras such as Hitchcock and others' Vascular Plants of the Pacific Northwest (1973), Davis's Flora of Idaho (1952), or Hultén's Flora of Alaska and Neighboring Territories (1968), and then view photographs of the plant in this book.

The book is organized alphabetically by family with descriptions of each. Although this approach is okay for its intended purpose, it could have been made more useful as a field guide by organizing along phylogenetic lines, by including keys for families, and keys to identify closely related species. Plant names follow the "Kartesz list" that is used in http://plants.usda.gov/plants.

The last section of the book is a concise overview of wildflower photography techniques. Beginning wildflower photographers would benefit from reading this section.

Idaho Mountain Wildflowers has very few errors and plant identification is accurate. I was confused about the statement on page 6 "temperatures fall about three degrees centigrade for every 1000 feet of ascent." This seems to be an oversimplification of moisture and elevational interactions and some clarifi-

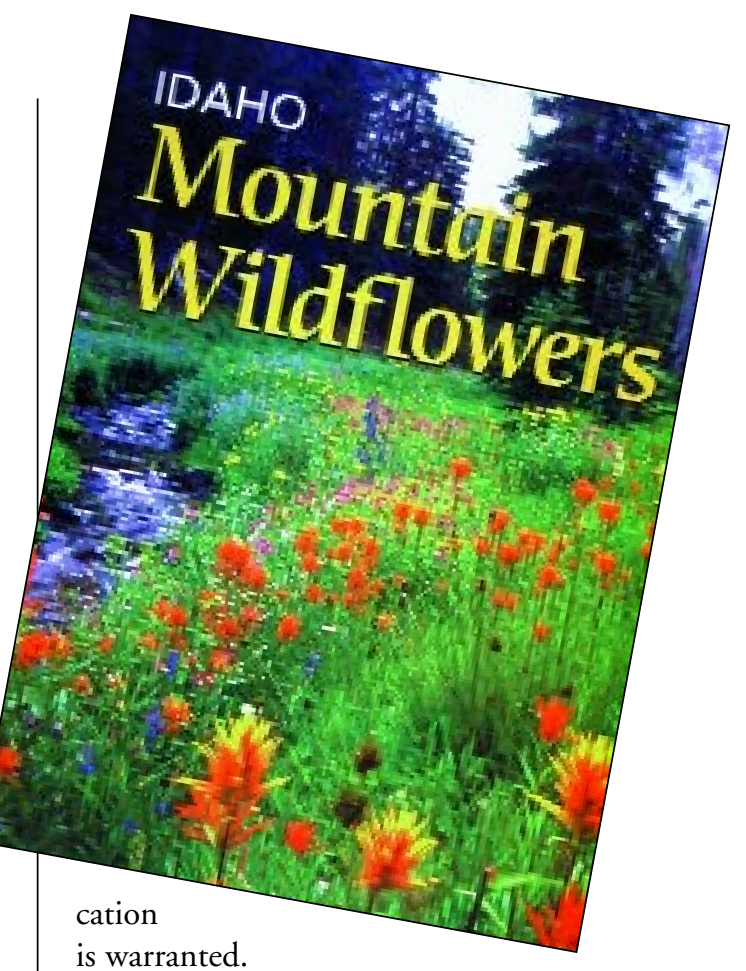

is warranted.

Comments on the possible positive effects of fertilization by sheep herding on several species of wildflowers were made without scientific documentation. These comments could be misleading and should be documented by credible scientific research that includes effects on the composition, structure, and function of the larger ecosystem involved. The Sawtooth Draft Forest Plan lists 8 species of rare plants threatened by livestock grazing and the Draft EIS for the Boise, Payette, and Sawtooth national forests list 30 species of rare plants that are negatively impacted by grazing.

All and all, this is an excellent book for a very reasonable price. I would recommend it to anyone who is interested in mountain plants. I am proud to have it in my library.

$$
\text { - Lynn Garrison }
$$

Lynn Garrison is the Division Director of Public Affairs for the Kentucky Department of Fish \& Wildlife Resources. He has a master of science degree in plant ecology from Eastern Kentucky University and has a strong interest in alpine plants. 